\title{
Multispecies Size Composition: A Conservative Property of Exploited Fishery Systems?
}

\author{
S. A. Murawski and J. S. Idoine \\ National Marine Fisheries Service, Northeast Fisheries Center \\ Woods Hole, Massachusetts 02543, USA
}

\begin{abstract}
During the past three decades the species composition and abundance of finfishes on Georges Bank has changed dramatically, as measured by standardized trawl surveys and fishery performance data. Notwithstanding the dramatic shifts in species composition, the aggregate size composition (normalized numbers-at-length) has remained relatively stable. The descending limb of the aggregate species numbers-at-length curve estimates the weighted average rates of survival and growth (cumulative energy transfer) from one length category to the next. Observed changes in the slope of the aggregate size composition on Georges Bank can be correlated with various stanzas in the exploitation regime. Similar studies from other temperate fishery ecosystems indicate much different characteristic slopes to the aggregate catch-at-length curves. The conservation of aggregate size composition within fishery ecosystems may be indicative of size-based trophic interrelationships that tend to buffer fish production at length against perturbations to particular species and/or length components in highly-networked food webs. If such feedback mechanisms exist, they have important implications for the development of long-term multispecies management policy. A modelling approach to multispecies length composition is outlined, along with data requirements for such analyses.
\end{abstract}

\section{Introduction}

With respect to ecosystem changes in the Northwest Atlantic over the past three decades, there is considerable literature and new research enumerating the substantial changes in species composition, abundance and production in a number of Northwest Atlantic areas. On Georges Bank, fishery production and fishable biomass have undergone profound changes (Brown et al., 1976; Clark and Brown, 1977; Grosslein et al., 1980; Anon., 1991; Mayo et al., 1992; Gabriel, 1992). During this threedecade period there have been three, more-or-less distinct fishery regimes on Georges Bank: (1) a highly selective fishery conducted primarily by the Coastal States which targeted cod, haddock and flounders, (2) advent of intensive fishing by the distant water fleet with a considerable expansion of the target species composition, and (3) the postextended jurisdiction phase, in which an intensive species-selective fishery was re-established by the Coastal States (Anon., 1991).

Our study is to consider how fishing has altered the interrelationships among biologically-interacting species in heavily exploited systems such as Georges Bank. One would assume that given the profound changes in biomass, production and species composition (Clark and Brown, 1977; Mayo et al., 1992), that food webs have undergone major restructuring, with energy transfer rates being ex- tensively modified. A dynamic energy budget for Georges Bank does not exist, although static calculations have been made (Cohen et al., 1982), and fluctuations in production and biomass documented (Grosslein et al., 1980). A mechanistic approach to evaluating the effects of harvesting on food web relationships involves intensive dietary studies, combined with extensive information on the time-trajectories of population sizes (e.g. Pope, 1991). Given the large number of predators and prey on Georges Bank (Grosslein et al., 1980) and the highly migratory nature of important components (Gabriel, 1992), such a comprehensive study is indeed a difficult undertaking. We propose there are other less datademanding indicators of ecosystem response, and they could suggest possible mechanisms of system homeostasis. In this paper we examine aspects of multispecies interactions using size-based indices of abundance and trophic interaction.

\section{Changes on Georges Bank}

Variation in the abundance and fishery productivity of the 'trawlable' component of the Georges Bank region has been monitored since the early1960s through research vessel trawl surveys (Clark and Brown, 1977; Mayo et al., 1992), and by commercial fishery sampling (Brown et al., 1976; Anon., 1991). The pelagic system components have been monitored primarily through fishery-dependent means (Grosslein et al., 1980; Anon., 1991). 
Bottom trawl surveys of the region have been conducted annually in the autumn since 1963 and in the spring since 1968 (Clark and Brown, 1977). Aggregate species catch-per-tow data for autumn bottom trawl surveys are given in Fig. 1. Total weight-per-tow declined steadily and significantly from $134 \mathrm{~kg} /$ tow in 1963 to a low of $60 \mathrm{~kg} /$ tow in 1971 $(-55 \%)$. During this period the character of the fishery changed from being highly species selective, targeting haddock, cod and flounders (by fleets of the Coastal States), to an intensive multi-national fishery, with a wider diversity of species targets. Concern for the status of resources on Georges Bank and elsewhere in the Northwest Atlantic led to restrictive catch and effort regulations in the early1970s. The extension of Coastal State jurisdiction was coincident with a rapid increase in total system biomass (as measured by aggregate weight/tow). The total fish biomass available to the bottom trawl has stabilized at levels equivalent to those exhibited before the advent of intensive distant water fleet fishing (Fig. 1). The total-species index in 1990 was $159 \mathrm{~kg} /$ tow.

One important aspect of the fluctuation in biomass of fishes on Georges Bank is the very apparent change in species composition of survey catches. During the 1960s, elasmobranchs comprised an average of $21 \%$ in weight of trawl survey catches on Georges Bank (Fig. 1). The proportion of elasmobranchs (skates and dogfish) increased steadily and significantly: to $39 \%$ of the total from 1970 to 1979, and to an average 61\% from 1980 to 1990. Abundance indices for primary commercial species (e.g. gadoids and flounders, which are the primary contributors to the 'other fish' component of the trawl survey) were highest in 1963-64, and again in 1976-78. Current indices of this component are

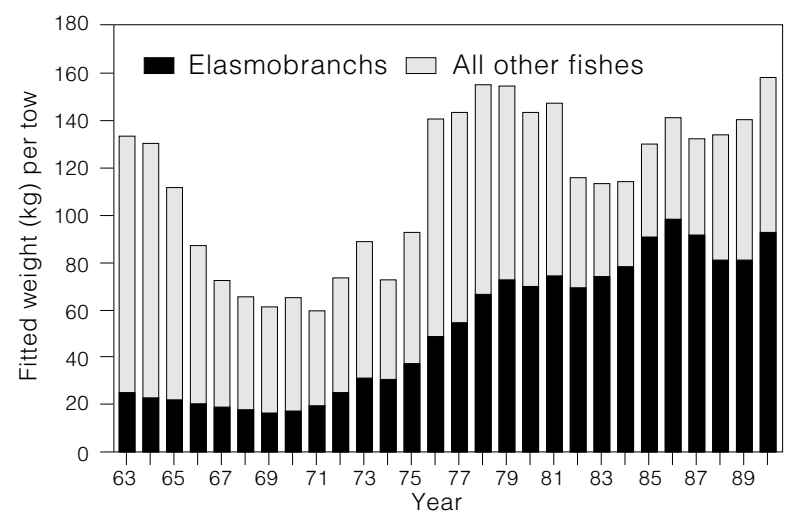

Fig. 1. Total weight-per-tow (kg, time-series smoothed) of finfishes taken in autumn bottom trawl surveys on Georges Bank, 1963-90. Data are aggregated into two classes: elasmobranchs (skates, dogfish and other sharks) and other finfishes (primarily gadoids, flatfishes and pelagics). about $65 \%$ of the peak abundance levels. Commercial fishery catch and effort data confirm the trend of decreasing abundance of 'marketable' species in recent years (Anon., 1991; Mayo et al., 1992).

Species compositions of landings have changed greatly with the various fishing regimes in place on Georges Bank. Before the advent of distant water fleet fishing, USA landings from Georges Bank were primarily haddock, cod and yellowtail flounder. Distant water fleets targeted an expanded species spectrum, and retained much of the by-catch for reduction. Thus, there were significant catches of elasmobranchs and other species now considered 'underfished' in the current USA fishery (Anon., 1991). Since the extension of fishery jurisdictions, trawl catches on Georges Bank were again dominated by a very few species: cod, winter flounder and yellowtail flounder.

The size composition of aggregate trawl survey catches from 1963 to 1985 are plotted in Fig. 2 $\left(\log _{10}\right.$ numbers-at-length) and Fig. 3 (numbers-atlength). These data indicate a slight reduction in the number and proportion of relatively large fish (>50 cm) during the period of intensive distant water fleet fishing in the mid-1960s to early-1970s. The average fish weight also declined slightly in this period. Since the mid-1970s, the number and proportion of fish in larger size categories has increased. Likewise, the average weight of fish has increased (except for 1985 when a very large yearclass of silver hake was encountered in the surveys). A large proportion of the fish $>70 \mathrm{~cm}$ is comprised of elasmobranchs ( $>80 \%$, Pope et al., 1987). Thus, the increase in abundance of elasmobranchs was mostly responsible for the increasing numbers of larger fish in the autumn surveys.

The Georges Bank trawl survey data were compared and contrasted with similar information for the North Sea by Pope et al. (1987). They noted the increase in the proportion of larger fish on Georges Bank as a decrease in the slope of the catch-atlength curve computed from annual data plotted in Fig. 2. Interestingly, although there were changes in the aggregate size composition of Georges Bank trawl catches, these differences were minor when the Georges Bank catch compositions were compared to data from the North Sea. The North Sea data exhibited a very much steeper slope (more rapid reduction in numbers-per-unit-length range). In the case of both systems, the differences in slopes between years were minor, as compared to differences in slopes between fishery ecosystems (Fig. 4). Pope and Knights (1982) reached a similar conclusion when comparing trawl catches from the Faroe Bank and the North Sea, and that conclusion was generally supported by additional analyses of 


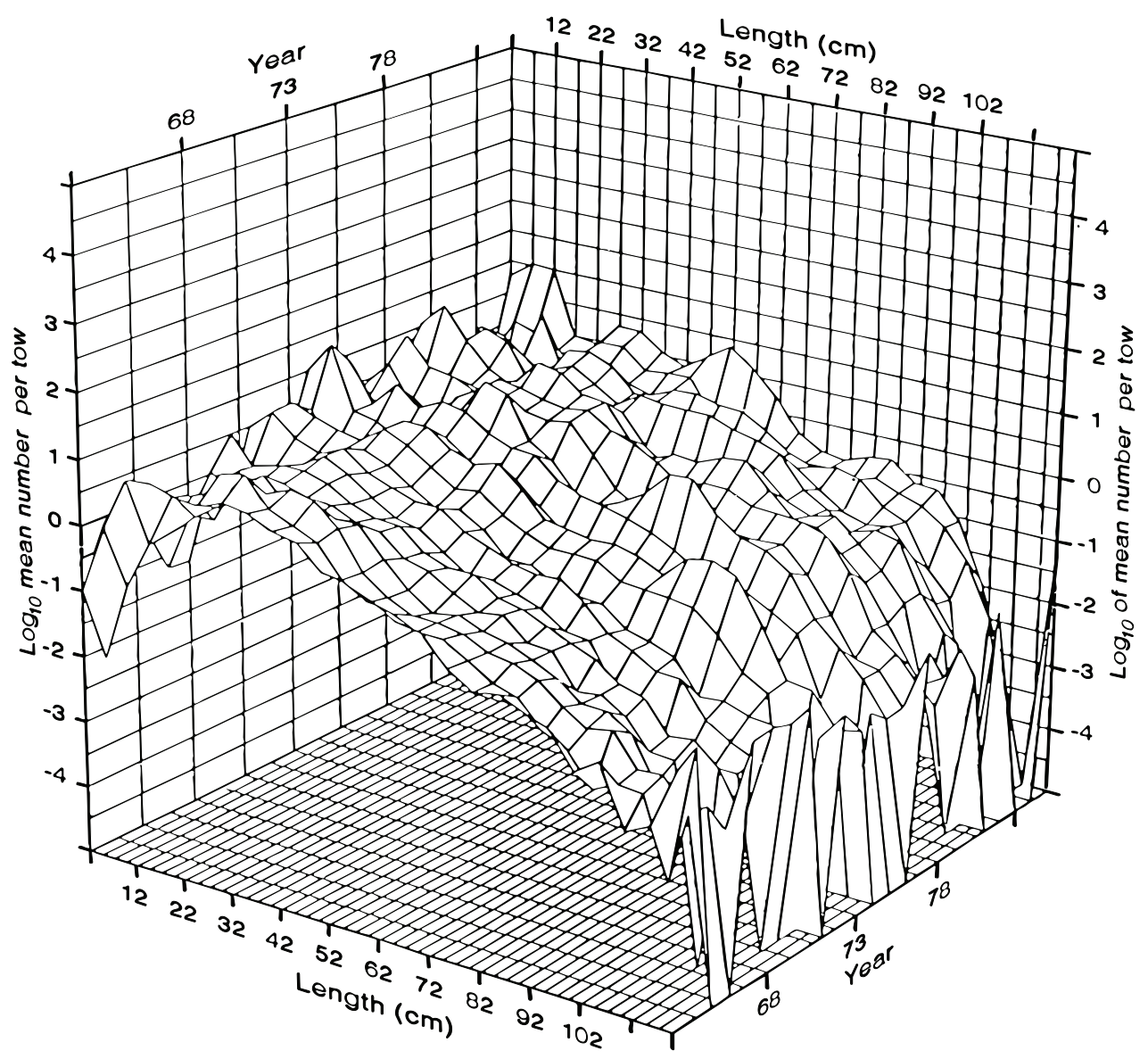

Fig. 2. $\log _{10}$ mean number-per-tow at length of finfishes taken in autumn bottom trawl surveys on Georges Bank, 1963-85. Catch data are aggregated into $5 \mathrm{~cm}$ length intervals.

trawl survey data from the North Sea, Georges Bank, and the Grand Banks of Newfoundland (Anon., MS 1991). Do these results indicate a conservative mechanism acting to structure predation and food availability along a continuum of fish body sizes, or is the observation of differing slopes of the cumulative catch-at-length curves among ecosystems simply a reflection of the weighted exploitation rates and availability to the sampling gear?

\section{Size-based Indices of Multispecies Systems}

Considerable contemporary research has identified energy transfer among size spectra as a structuring mechanism in marine communities (Sheldon et al., 1972; Platt and Denman, 1978; Silvert and Platt, 1980; Platt et al., 1981; Platt, 1985; Sprules and Munawar, 1986; Dickie et al., 1987; Beyer, 1989). Most of the theoretical work on size spectra has been based on numbers and biomass (weight) distributions along a continuum of weight intervals. Although fish data can be expressed in these weight spectra (e.g. Anon., 1991), it is often more convenient to express fishery survey data in length intervals. One may attribute the large apparent differences in multispecies size composition from research vessel surveys among ecosystems to three potential sets of factors: (1) the differences are a manifestation of the inherent trophodynamics (rates of predation mortality at length, and the proportion of total food comprised of fish) of each system, (2) the aggregate size differences reflect differing weighted exploitation patterns in the various systems, or (3) there are differential surveying biases by size among the areas.

Characteristic fish size compositions for particular areas may be indicative of system-dependent ecological or fishing-induced processes that act to constrain the size spectra of fishes, even though individual species undergo wide variations 


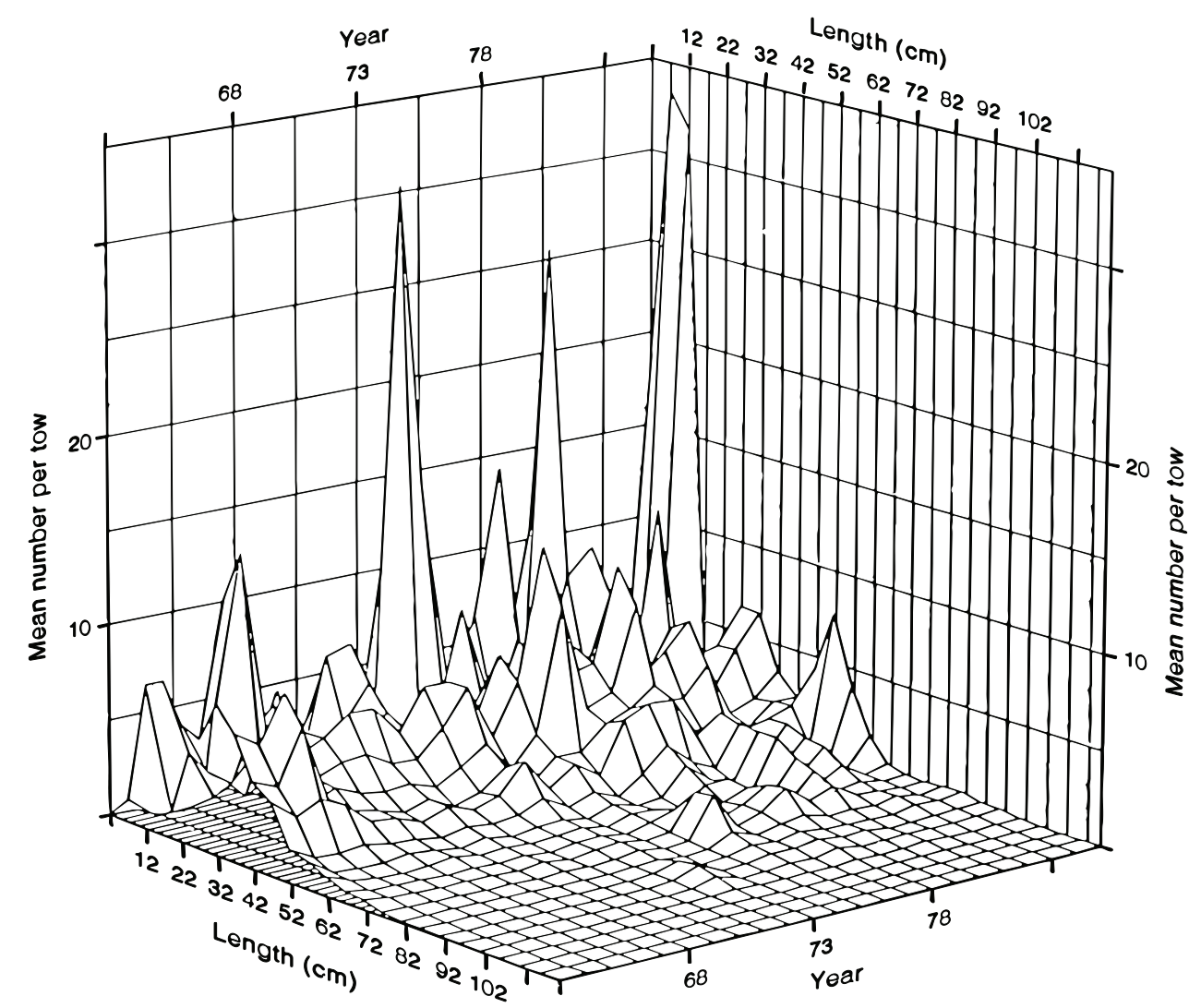

Fig. 3. Mean number-per-tow at length of finfishes taken in autumn bottom trawl surveys on Georges Bank, 1963-85. Catch data are aggregated into $5 \mathrm{~cm}$ length intervals.

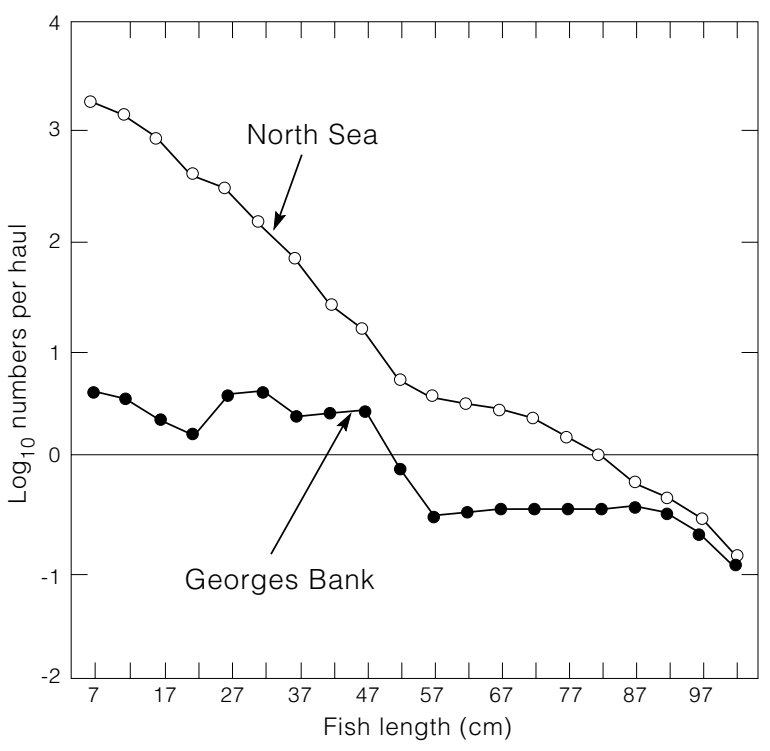

Fig. 4. Average size composition ( $\log _{10}$ numbers per tow at length) of finfishes taken in English Groundfish surveys of the North Sea and USA bottom trawl surveys of Georges Bank (adapted from data presented in Pope et al., 1987). in abundance. This is an interesting possibility and may serve as a mechanism to explain some cases of observed 'species replacement' in the Northwest Atlantic and elsewhere. The greater overall slope of the catch curve of numbers-at-length for the North Sea system (Fig. 4) is potentially related to both the fishing mortalities-at-length, and the relatively high predation mortality rates on young fish available to the trawl (Anon., 1991). North Sea fisheries tend to exploit fishes at a smaller size at first capture than on Georges Bank and the Grand Banks of Newfoundland. The regulated mesh size for primary gadoid and flounder species is $140 \mathrm{~mm}$ on Georges Bank and $90 \mathrm{~mm}$ in the North Sea. This would lead to increased skew of the catch curve to small-size fishes, in the case of the North Sea. If predation mortality rates are significantly greater in the North Sea system, consistent with the observation of a higher fraction of fish in the diets of North Sea predators (Ursin et al., 1985), then the North Sea catch curve would be more steeply skewed. If the differential predation rates on the fish component among systems in part explain the differences in aggregate length composition of the fish, then the inclusion of size spectra of invertebrate food would 
result in more comparable slopes of the size structure of the food web. If differences in the length composition of the aggregate fish biomass among systems are attributable to such mechanisms, then the trawl survey data represent an easily obtainable metric which may have great utility in examining intersystem differences in food web structure. Conversely, if the observed differences are due to sampling biases, then such comparisons are of limited value in intersystem comparisons of trophodynamics. Sampling biases may result from the differential catchability of small fish, resulting either from changing spatial availability by length category or due to gear/environmental interactions.

\section{Conservation of Size Composition?}

A characteristic slope to the biomass spectrum of animals in pelagic systems has been the subject of intense theoretical and empirical work (see references above). If in fact size structure is a characteristic property of a fishery ecosystem, how would conservation of size composition be maintained? Highly selective fishing, as practised by the USA fleets on Georges Bank, acts to select certain species and size groups from the available array at length. Currently the USA catches are dominated by cod (a partial piscivore) and flounders (primarily consuming benthic macrofauna). Given that these species may be selectively extracted from the ecosystem, it is plausible that dogfish and skates have increased in abundance to exploit available food resources, since the dietary overlaps between coddogfish and flounders-skates are generally high (Grosslein et al., 1980). Another potential mechanism supporting stability in size composition would be the effects of density-dependent growth. If density-dependent growth does occur for some gadoids (e.g. haddock) and flounders (e.g. yellowtail), then as the abundance of these species is reduced through fishing, increased growth may result in the remaining individuals of those species, and others with similar diet compositions. Higher growth rates would result in more rapid accumulation of biomass (numbers) in larger size intervals, thus partially compensating for high fishing mortality rates that tend to 'push-down' the right-hand limb of the aggregate size distribution.

Given the large number of predator and prey species in the Georges Bank (Gabriel, 1992) and North Sea (Anon., 1991) systems, compensations in size-based feeding niches is plausible. In highly networked feeding webs (such as these systems) replacement of functional predation and prey roles in a size-structured system can occur at time scales that would imply relative homeostasis in length composition (Pimm, 1991). Obviously, short-term intense perturbations such as rapid changes in ex- ploitation rates and patterns cannot be compensated for, even in highly networked systems. Such is the case on Georges Bank in the 1960s and early1970s, when total stock biomass fell by about $50 \%$, and the average size of the aggregate catch curve declined. For food web systems with few predators or that are based on a low diversity of important prey species, the potential for functional compensation in size-based feeding is less, and thus more variability in total production may be expected (Pimm, 1991).

\section{A Modelling Approach to Multispecies Size Composition}

The utility of size structure comparisons among exploited fishery systems will remain in doubt until the factors responsible for differences thus far observed can be evaluated. To do so, an analytical framework incorporating length-based rates of predation (M2) and fishing (F), and non-predation natural mortality (M1) rates and growth is required. The numbers of fish $(N)$ occurring in any length interval $\left(l_{1}>_{2}\right)$ is the integral over that size interval:

$$
N\left(l_{1}, l_{2}\right)=\int_{l_{1}}^{l_{2}} n(l) d l
$$

Changes in numbers over time (t) within the interval are due to two processes: (1) mortality rates of animals within the interval:

$$
\mathrm{dN}\left(\mathrm{I}_{1}, \mathrm{I}_{2}\right) / \mathrm{dt}=\int_{\mathrm{l}_{1}}^{\mathrm{l}_{2}} \mathrm{Z}(\mathrm{I}) \mathrm{n}(\mathrm{I}) \mathrm{dl}
$$

where;

$$
Z(I)=F+M 1+M 2(I)
$$

and (2) growth of animals into and out of the interval. Growth can be represented as a deterministic process in length, according to the von Bertalanffy model:

$$
I_{t+d t}=L_{\infty}\left(1-e^{-K d t}\right)+I_{t} e^{-K d t}
$$

or other appropriate formulation. When discrete size intervals are used, growth can be formulated as a transition probability matrix:

$$
\mathrm{l}_{\mathrm{t}+\mathrm{dt}}=\sum_{\mathrm{j}} \mathrm{p}_{\mathrm{j}} \overline{\mathrm{j}}_{\mathrm{j}}
$$

where; $p_{j}$ is the proportion of animals at $i_{j}$ growing into interval $j$ over $d t$, and $\bar{l}$ is the average length of animals in the length interval $\mathrm{j}$.

Predation mortality rates at length are a function of the numbers of potential prey within the length interval, and the suitability of those potential prey to the predator field. Size-based models of predator-prey interactions are well developed 
(Andersen and Ursin, 1977; Sprules and Munawar, 1986). The size interval of prey eaten by a predator of given size (length) is a function of its predation 'window' (variation in size of prey eaten for a given predator size), and the 'distance' (in body size intervals) between the size of the predator and its predation window. Some predators are capable of consuming animals over a wide length spectrum (e.g. cod), while others are more limited. A functional model of predation at length could be represented by a summation over all predator length intervals of the number of predators and their consumption at length. Adjustments in the species composition of prey and the predation window widths and distances would indicate the degree of compensation in relation to prey availability. Such a model could be constructed using available stomach sampling data for the Georges Bank and other fishery ecosystems (Anon., 1991). Development of such a model is requisite to deconvolving the various factors controlling apparent multispecies size compositions.

\section{Summary}

The existence of conservative mechanisms acting to maintain stable size distributions could potentially have important ramifications for the development of long-term management strategies. It may not necessarily be feasible from an energetics perspective to increase the minimum or average landed sizes of several fish species simultaneously, without decreasing the abundance of those or yet other species. If there is a limit on the proportion of biomass (numbers) by length interval, then 'stockpiling' of biomass in larger size intervals may result in reduced growth, delayed maturity, etc., resulting in increased 'transit times' between size increments. Similarly, if there are population mechanisms maintaining proportional size spectra in the fishes, it may not necessarily be feasible to increase the abundance of a particular species, in the presence of an established competitive population at the 'desired' size interval. For example, given the current high abundance of skates and dogfish, it may not be possible to increase gadoid and flounder abundance without 'extracting' some of the current standing stock. Thus, establishing the relative importance of factors determining sized-based biological interactions has important practical implications. Comparisons of trawl survey size compositions in various boreal temperate and tropical fishery ecosystems can potentially provide powerful new insights into the structure and functioning of exploited fishery systems.

\section{Acknowledgements}

We thank a variety of colleagues for their contributions to the genesis of this paper, including John
Pope, Jan Beyer and Frank Almeida, and especially the members of the Multispecies Working Group of ICES for their thoughtful critique of the concept.

\section{References}

ANDERSEN, K. P., and E. URSIN. 1977. A multispecies extension to the Beverton Holt theory of fishing, with accounts of phosphorous circulation and primary production. Medd. Dan. Fisk. Havunders, N.S.F., 7: 319345.

ANON., 1991. Status of the fishery resources off the northeastern United States for 1991. NOAA Tech. Mem., NMFS-F/NEC-86, $132 \mathrm{p}$.

MS 1991. Report of the Multispecies Assessment Working Group, Woods Hole, December, 1990. ICES C.M. Doc., No. 7 (Assess), 246 p.

BEYER, J. 1989. Recruitment stability and survival simple size-specific theory with examples from the early life dynamics of marine fish. Dana, 7: 45-147.

BROWN, B. E., J. A. BRENNAN, M. D. GROSSLEIN, E. G. HEYERDAHL, and R. C. HENNEMUTH. 1976. The effect of fishing on the marine finfish biomass in the Northwest Atlantic from the Gulf of Maine to Cape Hatteras. ICNAF Res. Bull., 12: 49-68.

COHEN, E. B., M. D. GROSSLEIN, M. P. SISSENWINE, F. STEIMLE, and W. R. WRIGHT. 1982. Energy budget of Georges Bank. In: Multispecies approaches to fisheries management advice. M. C. Mercer (ed.). Can. Spec. Publ. Fish. Aquat. Sci., 59: 95-107.

CLARK, S. H., and B. E. BROWN. 1977. Changes in biomass of finfishes and squids from the Gulf of Maine to Cape Hatteras, 1963-74, as determined from research vessel survey data. Fish. Bull. U.S., 75(1): 1-21.

DICKIE, L. M., S. R. KERR, and P. SCHWINGHAMMER. 1987. An ecological approach to fisheries assessment. Can. J. Fish. Aquat. Sci., 44: 68-74.

GABRIEL, W. L. 1992. Persistence of demersal fish assemblages between Cape Hatteras and Nova Scotia. J. Northw. Atl. Fish. Sci., this volume, p.2946.

GROSSLEIN, M. D., R. W. LANGTON, and M. P. SISSENWINE. 1980. Recent fluctuations in pelagic fish stocks of the Northwest Atlantic, Georges Bank region, in relation to species interactions. ICES Rapp. Proc.-Verb., 177: 374-404.

MAYO, R. K., M. J. FOGARTY, and F. M. SERCHUK. 1992. Aggregate fish biomass and yield on Georges Bank, 1960-1987. J. Northw. Atl. Fish. Sci., this volume, p. 59-78.

PIMM, S. L. 1991. The balance of nature? Ecological issues in the conservation of species and communities. University of Chicago Press, $434 \mathrm{p}$.

PLATT, T. 1985. Structure of the marine ecosystem: Its allometric basis. Can. Bull. Fish. Aquat. Sci., 213: 55-64.

PLATT, T., and K. DENMAN. 1978. The structure of pelagic marine ecosystems. ICES Rapp. Proc.-Verb., 173: $60-65$.

PLATT, T., K. H. MANN, and R. E. ULANOWICZ (eds.). 1981. Mathematical models in biological oceanography. UNESCO Press, Paris, $157 \mathrm{p}$.

POPE, J. G. 1991. The ICES Multispecies Assessment Working Group: evolution, insights, and future problems. ICES Marine Science Symposia, 193: 22-33.

POPE, J. G., and B. J. KNIGHTS. 1982. Comparison of 
length distributions of combined catches of all demersal fishes in surveys in the North Sea and at Faroe Bank. In: Multispecies approaches to fisheries management advice. M. C. Mercer (ed.) Can. Spec. Publ. Fish. Aquat. Sci., 59: 116-118.

POPE, J. G., T. K. STOKES, S. A. MURAWSKI, and J. S. IDOINE. 1987. A comparison of fish size-composition in the North Sea and on Georges Bank. p. 146152. In: Ecodynamics, contributions to theoretical ecology. W. Wolff, C.-J. Soeder, and F. R. Drepper (eds.) Julich, Federal Republic of Germany.

SHELDON, R. W., A. PRAKASH, and W. H. SUTCLIFFE, Jr. 1972. The size distribution of particles in the ocean.
Limnol. Oceanogr., 17:: 327-340.

SILVERT, W., and T. PLATT. 1980. Dynamics energy-flow model of the particle size distribution in pelagic ecosystems. p. 754-763. In: Evolution and ecology of zooplankton communities. W. C. Kerfoot (ed.) Univ. Press of New England, Hanover, New Hampshire.

SPRULES, W. G., and M. MUNAWAR. 1986. Plankton size spectra in relation to ecosystem productivity size and perturbation. Can. J. Fish. Aquat. Sci., 43: 17891794.

URSIN, E., M. PENNINGTON, E. B. COHEN, and M. D. GROSSLEIN. 1985. Stomach evacuation rates of Atlantic cod, Gadus morhua, estimated from stomach contents and growth rates. Dana, 5: 63-80. 
Blank 